\title{
LABORATORY STATION FOR RELIABILITY TESTING OF DIGITAL CIRCUITS USING SIGNATURE ANALYSIS
}

\section{STANOWISKO LABORATORYJNE DO BADANIA NIEZAWODNOŚCI UKŁADÓW CYFROWYCH Z WYKORZYSTANIEM ANALIZY SYGNATUR}

\author{
Kamila Jadczak, Rafał Białek \\ Military University of Technology, Wojskowa Akademia Techniczna
}

\begin{abstract}
The article presented a laboratory station for diagnosing the digital circuits and the test results on the basis of a selected example. The idea of a response compression technique, which is called an analysis of signatures, was demonstrated. The main element of the station includes 8-bit programme of an analyser of signatures, which was developed by the authors, and implemented in the LabVIEW environment with the use of NI 6008 data analysis module. The programme operation was tested on the selected digital circuit, and the obtained results were provided in the article.
\end{abstract}

Keywords: signature analysis, diagnosis of digital systems

Streszczenie: $W$ artykule zaprezentowano stanowisko laboratoryjne do diagnozowania układów cyfrowych oraz wyniki badań na wybranym przykładzie. Zaprezentowano idee techniki kompresji odpowiedzi zwana analiza sygnatur. Głównym elementem stanowiska jest opracowany przez autorów program 8-bitowego analizatora sygnatur wykonany $w$ środowisku LabVIEW zwykorzystaniem modutu analizy danych NI 6008. Działanie programu przetestowano na wybranym uktadzie cyfrowym, a otrzymane wyniki zamieszczono $w$ artykule.

Stowa kluczowe: analiza sygnatur, diagnostyka uktadów cyfrowych 
Laboratory station for reliability testing of digital circuits using signature analysis Stanowisko laboratoryjne do badania niezawodności układów cyfrowych...

\section{LABORATORY STATION FOR RELIABILITY TESTING OF DIGITAL CIRCUITS USING SIGNATURE ANALYSIS}

\section{Introduction}

The basic problem in diagnosing and testing of digital circuits includes an analysis of long binary sequences, which occur on all nodes of the digital device during its operation. A binary stream that occurs in the circuit internal node depends on a signal stimulating a given circuit, and on its correct or incorrect operation. One of the methods for diagnosing of digital circuits is the comparison with a model. Having the knowledge about the response of the correctly operating circuit, it is possible to diagnose the circuit by comparing this response with the tested circuit response. However, in case of very long binary sequences, the performance of the analysis and comparison with a given model is very cumbersome and timeconsuming. In order to simplify the analysis of such a signal, the response compression techniques, that is the signal conversion to a shorter clearer form, the so-called signature, are used.

\section{Analysis of Signatures}

The technique called the analysis of signatures is based on the circuit response compression to a shorter form. The sequence of bits from a specified test point in the tested circuit passes through another circuit, the so-called analyser of signatures, which generates a short bit sequence at the output that corresponds to an input sequence. The obtained sequence is called the signature, and it is then compared with the correct signature obtained as a result of: testing the correctly operating circuit or simulation. It always has the same number of bits, regardless of the input sequence length. 16-bit analysers are practically used. The diagram illustrating the method was shown in Fig. 1.

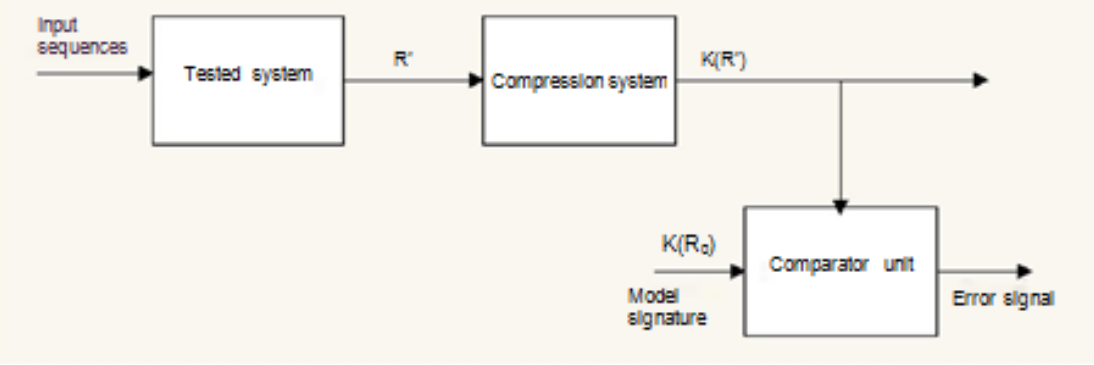

Fig. 1 Block diagram illustrating the technique of the analysis of signatures

The method for generating the signature is derived from the technique of CRC (Cyclic Redundancy Checks). The basic element of the circuit of the analyser of signatures is a shift register with LFSR (Linear Feedback Shift Register). 
The register creates $\mathrm{n}$ of D-type flip-flops, and the feedback is implemented with the use of XOR gates[1,7]. The general diagram of such a register was presented in Fig. 2.

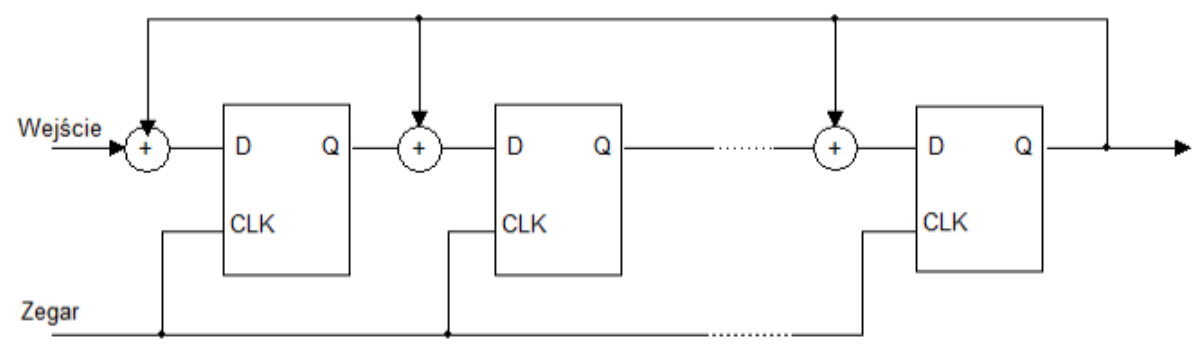

Fig. 2 Diagram of the shift register with feedbacks

The analysis of signatures is a very good diagnostic tool. The analyser circuit built on the shift register, which has at least one XOR gate, detects all single errors of the input sequence. If the occurrence of erroneous response bits is equally probable, then the probability of the situation that n-bit analyser of signatures will not detect the error is [1]:

$$
P(M)=\frac{2^{m-n}-1}{2^{m}-1}
$$

where:

$\mathrm{m}$ - input sequence length

$\mathrm{n}$ - register length

For $m \gg n$ :

$$
\lim _{m \rightarrow \infty} P(M)=2^{-n}
$$

The probability of the erroneous sequence detection does not depend on the input sequence length. The example values of the probabilities are presented in Table 1.

Tab. 1 Example values of the probability of the erroneous sequence detection by the analyser of signatures

\begin{tabular}{|c|c|}
\hline LFSR register length & $\begin{array}{c}\text { Probability of the erroneous } \\
\text { sequence detection }\end{array}$ \\
\hline 3 & $87.50 \%$ \\
\hline 4 & $93.75 \%$ \\
\hline 8 & $99.98 \%$ \\
\hline 16 & $99.998 \%$ \\
\hline
\end{tabular}


Laboratory station for reliability testing of digital circuits using signature analysis Stanowisko laboratoryjne do badania niezawodności układów cyfrowych...

\section{Analyser of signatures in the LabVIEW environment}

The article presents a programme of the analyser of signatures developed in the LabVIEW environment, with the use of NI 6008 data acquisition module of National Instruments company. The developed application allows to create 8-bit signature of any digital circuit with no more than 8 inputs. NI 6008 data acquisition module serves both as a generator of logic states and as an analyser of outputs of the tested circuit. The programme is intended for educational purposes in order to introduce students to the idea of the analysis of signatures and testing of digital circuits. In the LabVIEW environment, the 8-bit shift register with a feedback, which is implemented on one XOR gate, was designed. The diagram of the used register is shown in Fig. 3.

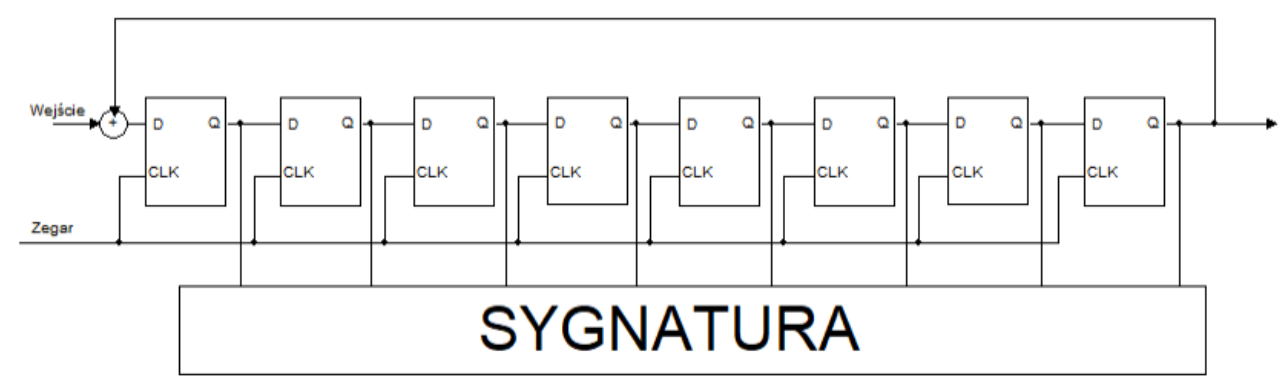

Fig. 3 Diagram of the shift register applied in the programme

The front panel of the implemented application was presented in Fig. 4.

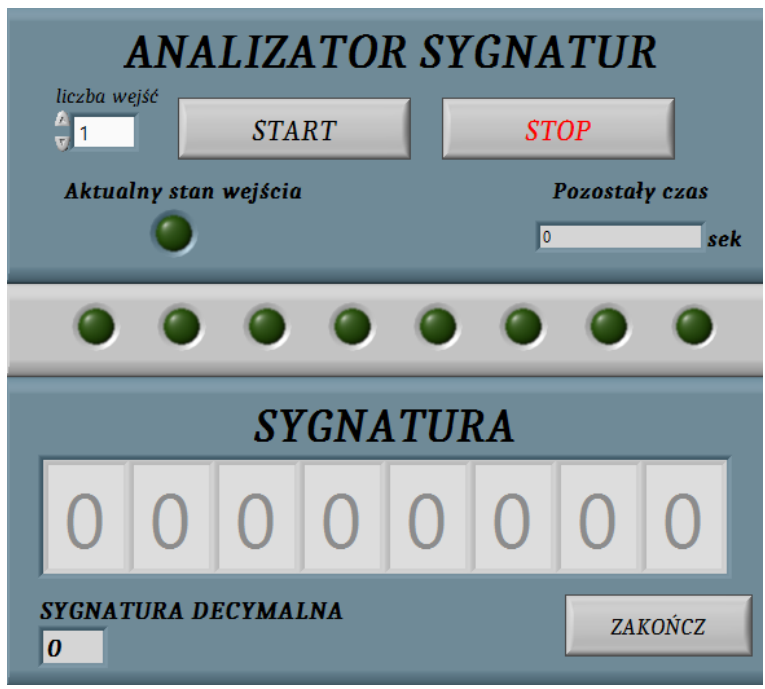

Fig. 4 Front panel of the application of the Analyser of Signatures 
The laboratory station of the analyser of signatures includes: PC computer with the implemented application, NI 6008 data acquisition module and combinational logic circuit, which implement a given function.

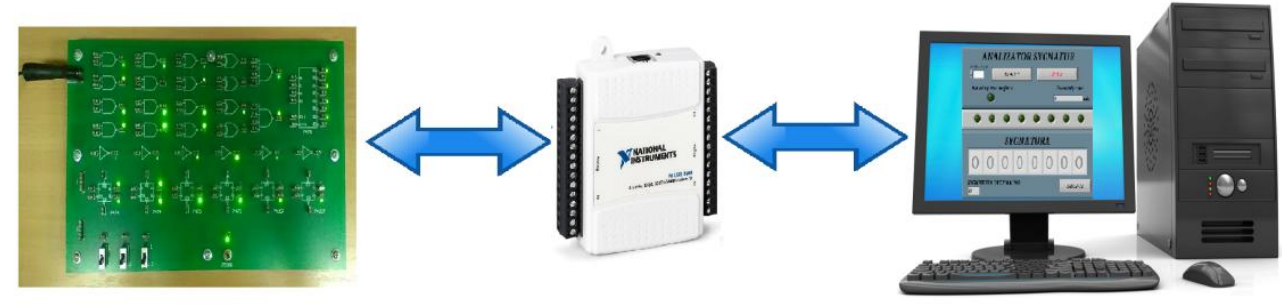

Fig. 5 Laboratory station diagram

After starting the application, the user can declare a number of inputs of the analysed circuit, to which a test sequence will be given. The provision of the introduction of a number of inputs of the tested circuit results in the fact that the programme is universal and suitable both for simple logic circuits and more complex ones. In addition, this function allows to test the circuit in its various points. After clicking the START button, the programme starts the signature generation. This process can be observed on an ongoing basis on eight "diodes" placed in the central part of the panel. Additionally, the information on the time remaining until the end of the analysis, as well as on the current state of the tested circuit output is displayed. After the analysis completion, the signature in the binary and decimal forms appears on the screen. Due to the educational purpose of the programme, a time of the generated each test states is 1 second. It allows to observe the changes of states in the register by students on an ongoing basis.

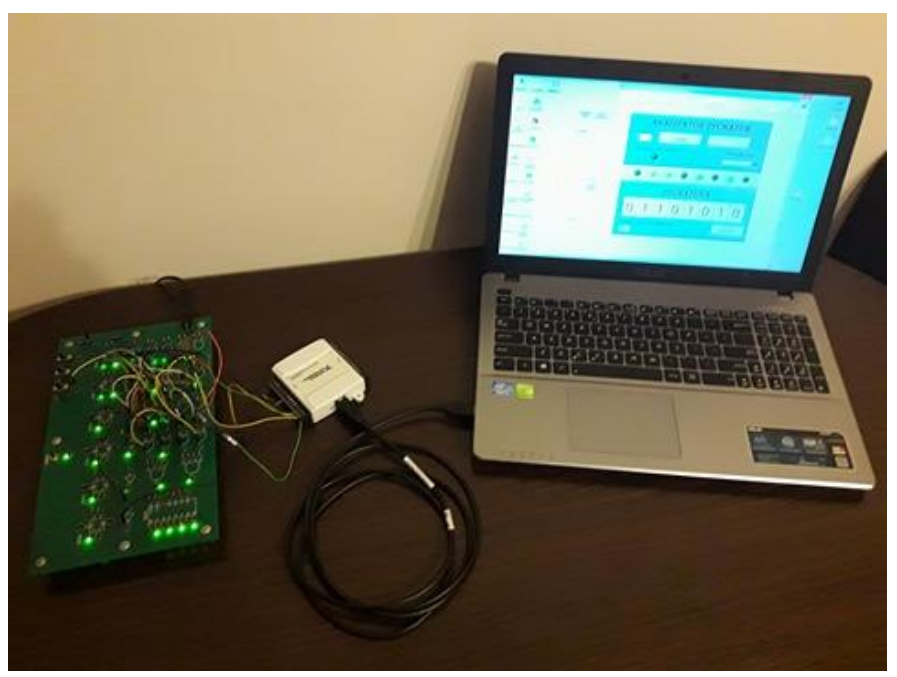

Fig. 6 Laboratory stations 
Laboratory station for reliability testing of digital circuits using signature analysis Stanowisko laboratoryjne do badania niezawodności układów cyfrowych...

\section{Logic circuit testing}

The presented programme of the analyser of signatures was used for testing the logic circuit built on gates and having 4 inputs and 1 output. The circuit diagram and a truth table were presented in Fig. 7

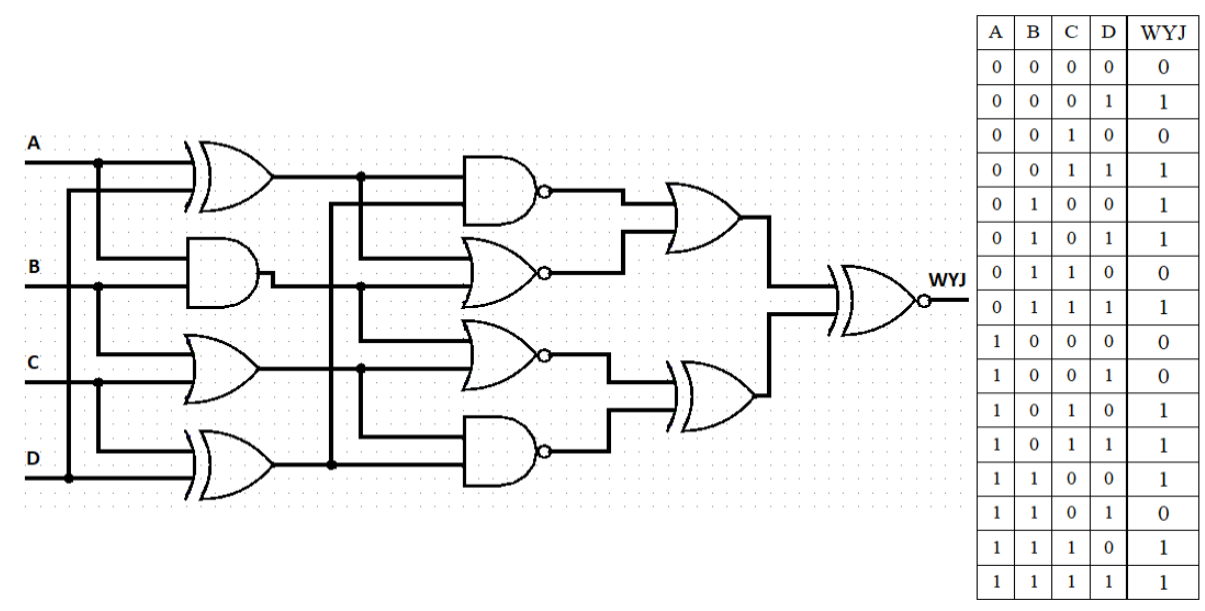

Fig. 7 Diagram of the tested circuit and the truth table

The tested circuit was connected to NI 6008 data acquisition module, which is responsible for communication with a computer. On the application front panel, a proper number of inputs (4 in case of this circuit) was introduced. After pressing the START button, the process of the signature determination begins. The view of the panel during the signature generation was presented in Fig. 8.

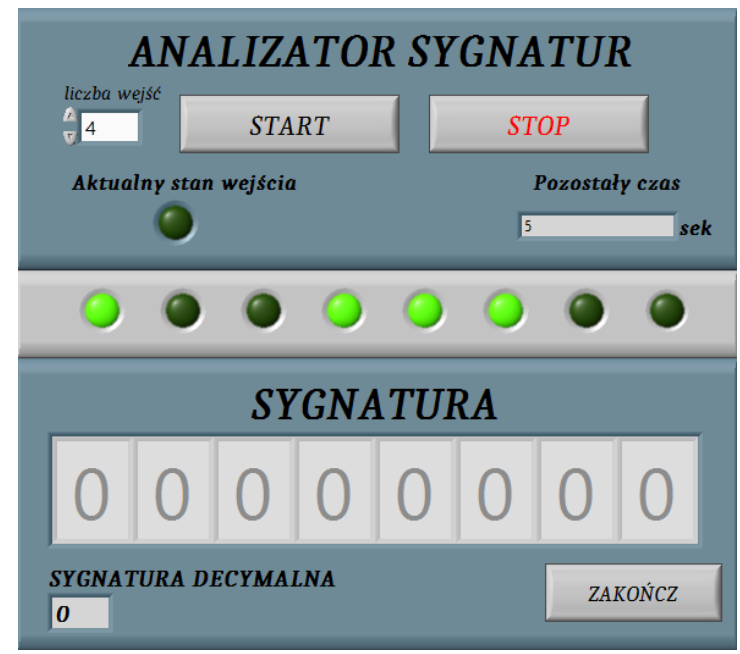

Fig. 8 View of the front panel during the signature generation 
During the programme operation, all the possible states are given to the tested circuit input, and a response, on the basis of which the signature is generated, is read on the output. After the programme operation completion, it is possible to read the created 8-bit signature from the display.

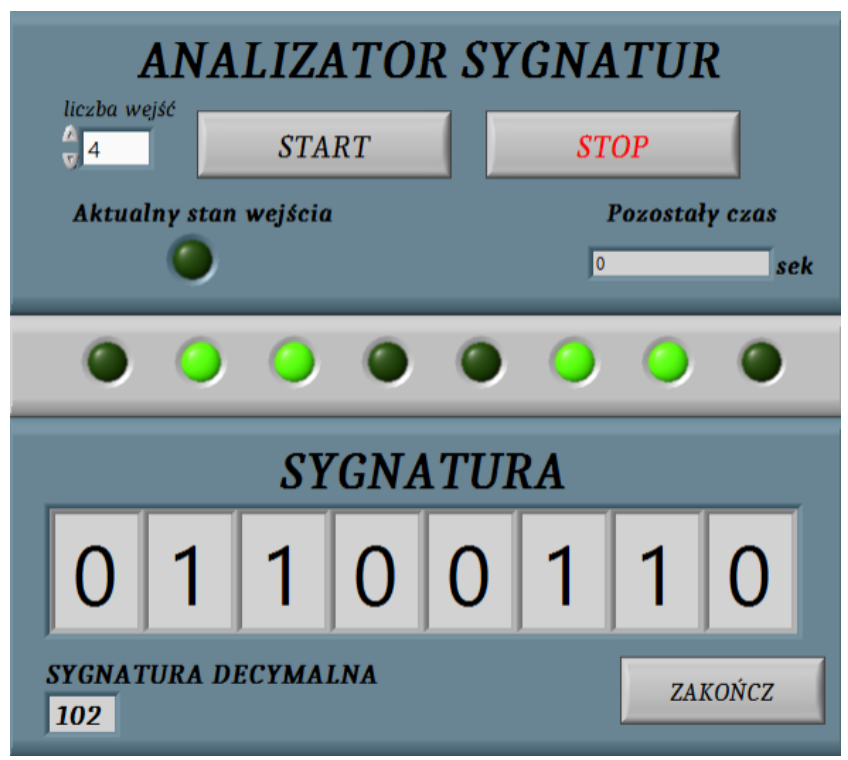

Fig. 9 View of the front panel after the analysis performance

After carrying out the test on the correctly operating circuit, 2 damages in the randomly selected places of the circuit were sequentially introduced. As damage, provide "zero" to enter the gate in the place marked in the Fig. 10. and Fig. 11.

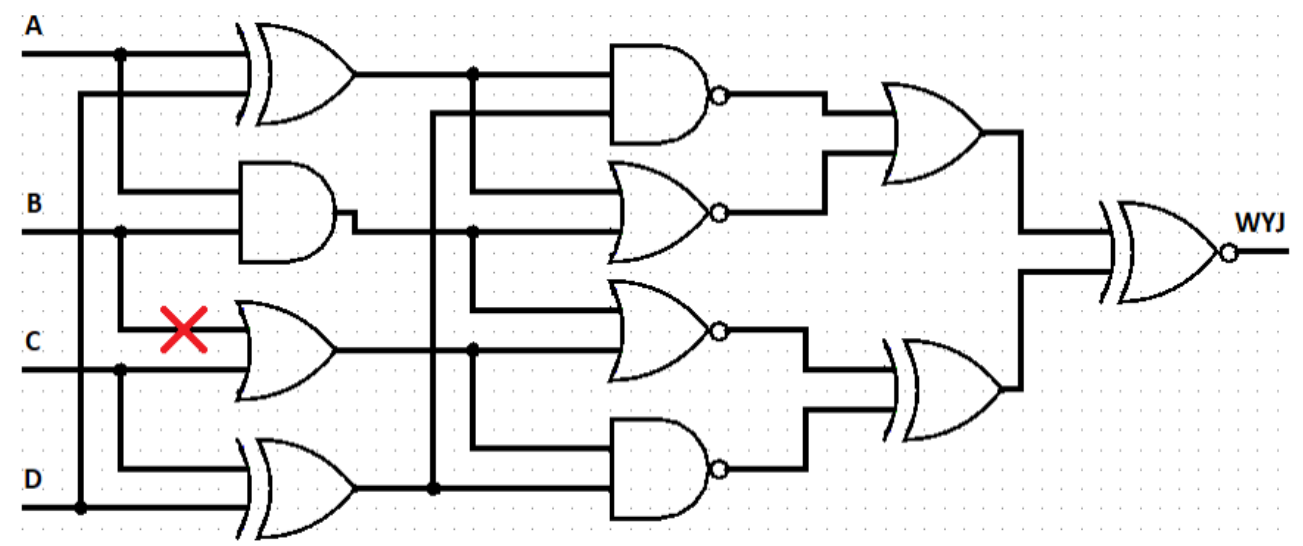

Fig. 10 Tested circuit with the introduced damage 1 
Laboratory station for reliability testing of digital circuits using signature analysis Stanowisko laboratoryjne do badania niezawodności układów cyfrowych...

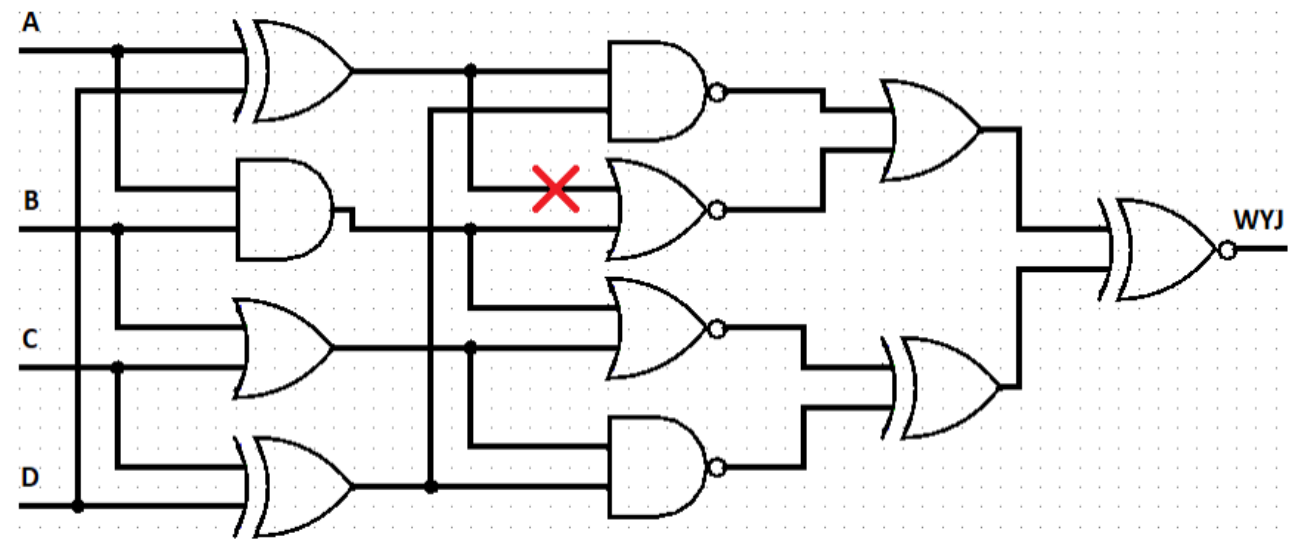

Fig. 11 Tested circuit with the introduced damage 2

The analysis was performed again, this time obtaining the signatures presented in Fig. 12 and Fig. 13

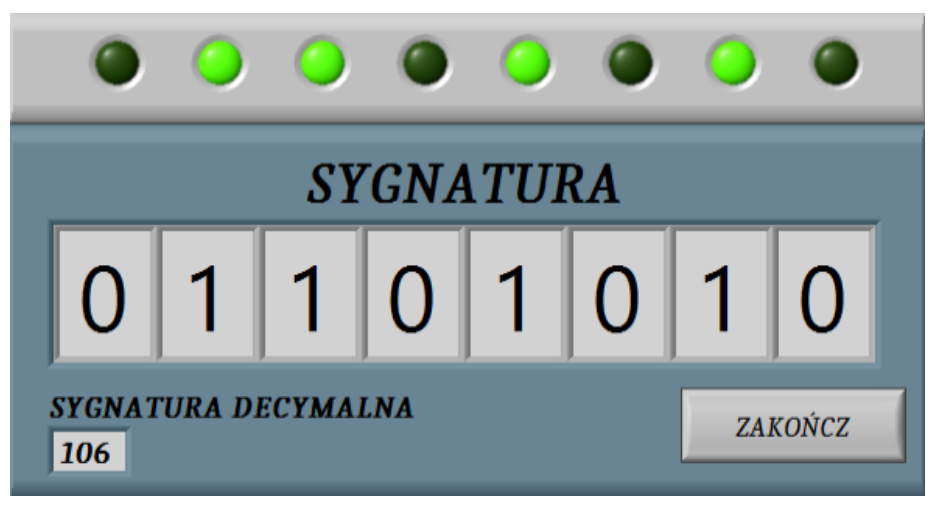

Fig. 12 Signature obtained for the damaged circuit - damage 1

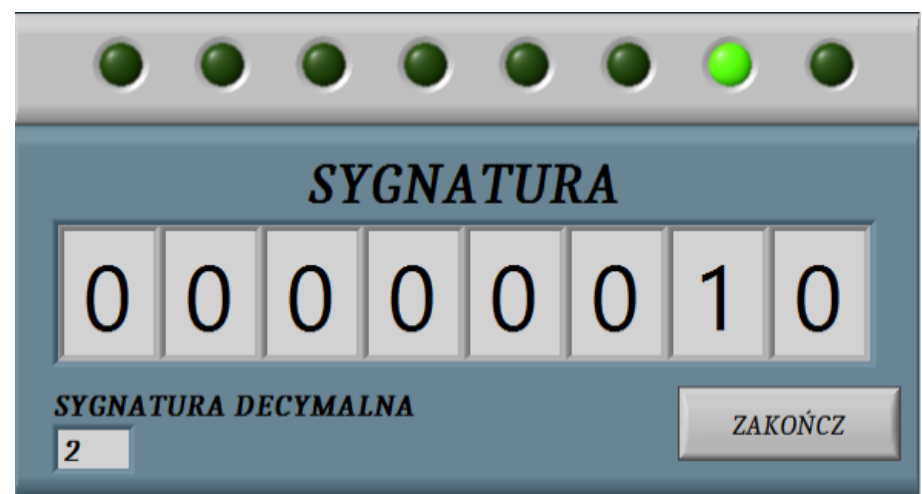

Fig. 13 Signature obtained for the damaged circuit - damage 2 
It can be noticed that the signature obtained as a result of the circuit correct operation is different than in case of the circuit with damage. In addition, a different signature was obtained for each damage.

\begin{tabular}{|c|c|}
\hline Damage & Signature \\
\hline - & 01100110 \\
\hline 1 & 00000010 \\
\hline 2 & 01101010 \\
\hline
\end{tabular}

\section{Conclusions}

In the article, a technique of diagnosing the digital circuits, called the analysis of signatures, was presented. The programme of the Analyser of Signatures developed in the LabVIEW environment with the use of NI 6008 data analysis module was demonstrated. It was developed for educational purposes in order to introduce students to a digital technique and one of the methods for testing the digital circuits. The operation of the developed programme was presented on the basis of the selected digital circuit. The signature of the correctly operating circuit was determined, and then, two random damages were sequentially introduced, and the signatures were compared. The example laboratory exercise may involve the determination of signatures of each node of the combinational logic circuit previously designed by students. Then, a single damage will be introduced to the circuit by a coordinator. The students' task will be to find a place of the failure occurrence by determination of signatures of individual nodes and their comparison with those previously obtained. The performed Analyser of Signatures can be used for creation of a library of signatures, in which the damages corresponding to given sequences will be described. In the future, such a library will significantly simplify checking of the digital circuit correct operation, and it will allow for a quick diagnosis of the failure occurrence.

\section{References}

[1] Frohwerk, Robert A. "Signature analysis: A new digital field service method." Hewlett-Packard Journal 28.9 (1977): 2-8.

[2] Chruściel, Marcin. LabVIEW w praktyce. Wydawnictwo btc, 2008.

[3] Głocki, Wojciech. Układy cyfrowe: podręcznik dla technikum. WSiP, 1996.

[4] Holdsworth, Brian, and Clive Woods. Digital logic design. Newnes, 2002.

[5] Parchański, Józef. Miernictwo elektryczne i elektroniczne. WSiP, 2014. 
Laboratory station for reliability testing of digital circuits using signature analysis Stanowisko laboratoryjne do badania niezawodności układów cyfrowych...

[6] Tłaczała, W. "Środowisko LabVIEW w eksperymencie wspomaganym komputerowo Wyd." Naukowo Techniczne Warszawa, 2002.

[7] Wang, Francis. "BIST using pseudorandom test vectors and signature analysis." Custom Integrated Circuits Conference, 1988., Proceedings of the IEEE 1988. IEEE, 1988.

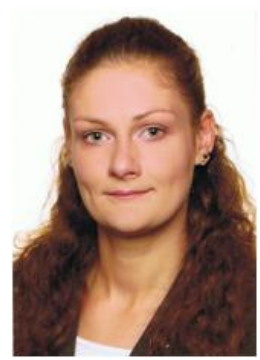

Mgr inz. Kamila Jadczak - a research and didactic assistant in the Department of Measurement and Information Systems of Military University of Technology. Research interests include the issues, among others, of machine learning and electronics in medicine. (Share 50\%)

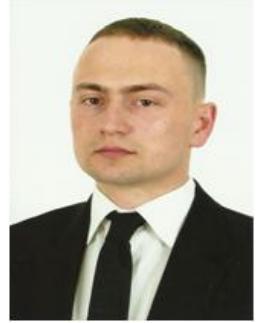

Mgr inz. Rafat Biatek- a research and didactic assistant in the Department of Measurement and Information Systems of Military University of Technology. Research interests include the measurements of high-power electromagnetic pulses and the design of high-power switching mode systems. (Share 50\%) 


\section{STANOWISKO LABORATORYJNE DO BADANIA NIEZAWODNOŚCI UKŁADÓW CYFROWYCH Z WYKORZYSTANIEM ANALIZY SYGNATUR}

\section{Wstęp}

Podstawowym problemem w diagnozowaniu i testowaniu systemów cyfrowych jest analiza długich ciągów binarnych występujących na wszystkich węzłach urządzenia cyfrowego podczas jego pracy. Strumień binarny występujący w wewnętrznym węźle układu zależy od sygnału pobudzającego dany układ i od jego poprawnej lub niepoprawnej pracy. Jednym ze sposobów diagnozowania układów cyfrowych jest porównywanie $\mathrm{z}$ wzorcem. Znając odpowiedź układu pracującego poprawnie można diagnozować układ poprzez porównanie tej odpowiedzi z odpowiedzią testowanego układu. Jednak w przypadku bardzo długich ciąów binarnych przeprowadzenie analizy oraz porównanie $\mathrm{z}$ wzorcem jest bardzo uciążliwe i czasochłonne. W celu uproszczenia analizy takiego sygnału stosuje się techniki kompresji odpowiedzi, a więc przekształcenie sygnału do krótszej, bardziej czytelnej postaci zwanej sygnaturą.

\section{Analiza Sygnatur}

Technika zwana analizą sygnatur opiera się na kompresji odpowiedzi układu do krótszej postaci. Sekwencja bitów z określonego punktu testowego w badanym obwodzie, przechodzi przez inny obwód zwany analizatorem sygnatur, który na wyjściu generuje krótką bitową sekwencję odpowiadającą sekwencji wejściowej. Otrzymana sekwencja nazywa się sygnaturą i jest następnie porównywana $\mathrm{z}$ sygnaturą prawidłową uzyskaną $\mathrm{w}$ wyniku: przebadania układu pracującego poprawnie lub symulacji. Zawiera ona zawsze tę samą liczbę bitów, niezależnie od długości sekwencji wejściowej. Praktycznie używane są analizatory 16-bitowe. Diagram ilustrujący metodę pokazano na rysunku 1.

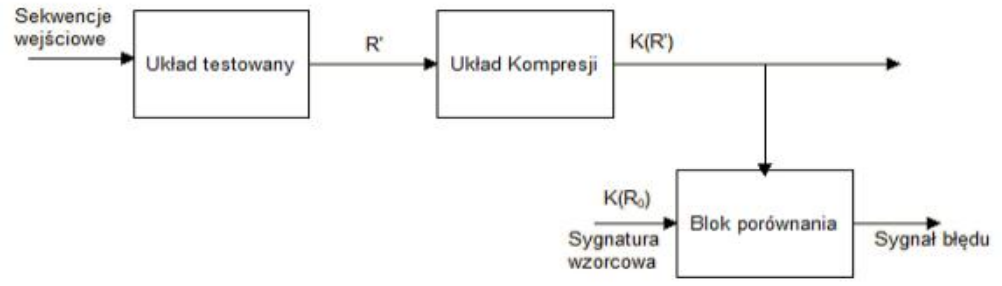

Rys. 1 Schemat blokowy ilustrujacy technikę analizy sygnatur

Sposób generowania sygnatury wywodzi się z techniki cyklicznych kodów nadmiarowych CRC (ang. Cyclic Redundancy Checks). Podstawowym elementem obwodu analizatora sygnatur jest rejestr przesuwny ze sprzężeniem zwrotnym LFSR (ang. Linear Feedback Shift Register). Rejestr tworzy n przerzutników D, a sprzężenie zwrotne jest zrealizowane przy użyciu bramek XOR[1,7]. Ogólny schemat takiego rejestru przedstawiono na rysunku 2. 
Laboratory station for reliability testing of digital circuits using signature analysis Stanowisko laboratoryjne do badania niezawodności układów cyfrowych...

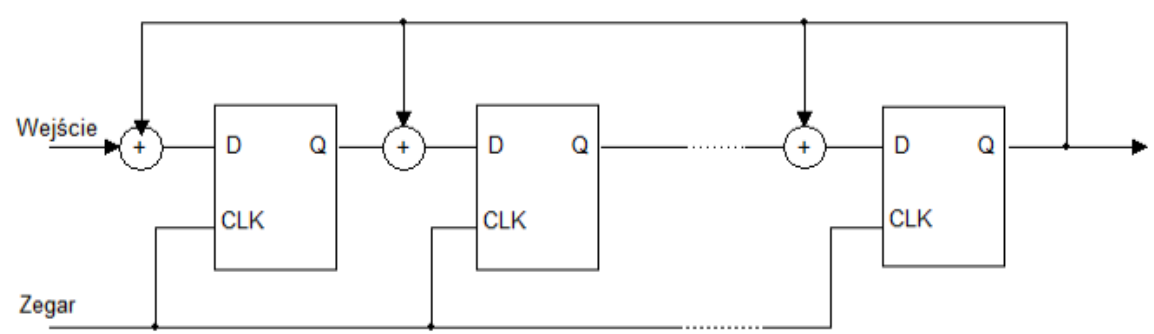

Rys. 2 Schemat rejestru przesuwnego ze sprzężeniami zwrotnymi

Analiza sygnatur jest bardzo dobrym narzędziem diagnostycznym. Układ analizatora zbudowany na rejestrze przesuwnym, posiadającym przynajmniej jedną bramkę XOR, wykrywa wszystkie pojedyncze błędy sekwencji wejściowej. Jeżeli wystąpienie błędnych bitów odpowiedzi jest jednakowo prawdopodobne, to prawdopodobieństwo tego, że n-bitowy analizator sygnatur nie wykryje błędu wynosi [1]:

$$
P(M)=\frac{2^{m-n}-1}{2^{m}-1}
$$

gdzie: $\mathrm{m}$ - długość sekwencji wejściowej, $\mathrm{n}$ - długość rejestru

Dla $m>n$ :

$$
\lim _{m \rightarrow \infty} P(M)=2^{-n}
$$

Prawdopodobieństwo wykrycia błędnej sekwencji nie zależy od długości sekwencji wejściowej. Przykładowe wartości prawdopodobieństw prezentuje tabela 1.

Tab. 1 Przykladowe wartości prawdopodobieństwa wykrycia przez analizator sygnatur błędnej sekwencji

\begin{tabular}{|c|c|}
\hline Długość rejestru LFSR & $\begin{array}{c}\text { Prawdopodobieństwo } \\
\text { wykrycia błędnej sekwencji }\end{array}$ \\
\hline 3 & $87,50 \%$ \\
\hline 4 & $93,75 \%$ \\
\hline 8 & $99,98 \%$ \\
\hline 16 & $99,998 \%$ \\
\hline
\end{tabular}

\section{Analizator sygnatur w środowisku LabVIEW}

$\mathrm{W}$ artykule przedstawiono program analizatora sygnatur opracowany w środowisku LabVIEW, z wykorzystaniem modułu akwizycji danych NI 6008 firmy National Instruments. Wykonana aplikacja umożliwia utworzenie 8-bitowej sygnatury dowolnego układu cyfrowego, posiadającego nie więcej niż 8 wejść. Moduł akwizycji danych NI 6008 pełni rolę zarówno generatora stanów logicznych jak i analizatora wyjść badanego układu. 
Program ma służyć do celów dydaktycznych, aby zapoznać studentów z ideą analizy sygnatur i testowania układów cyfrowych. W środowisku LabVIEW zaprojektowano 8-bitowy rejestr przesuwny ze sprzężeniem zwrotnym zrealizowanym na jednej bramce XOR. Schemat wykorzystanego rejestru przedstawia rysunek 3 .

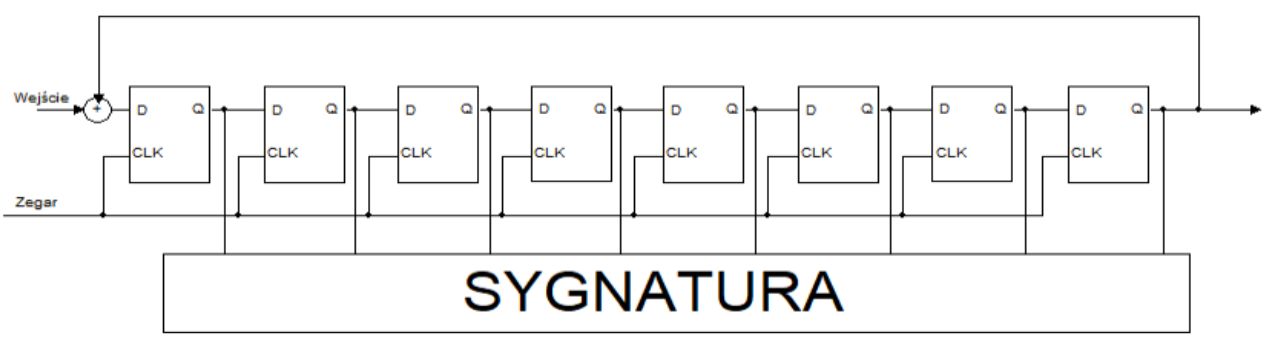

Rys. 3 Schemat rejestru przesuwnego wykorzystanego w programie

Panel czołowy wykonanej aplikacji przedstawiono na rysunku 4.

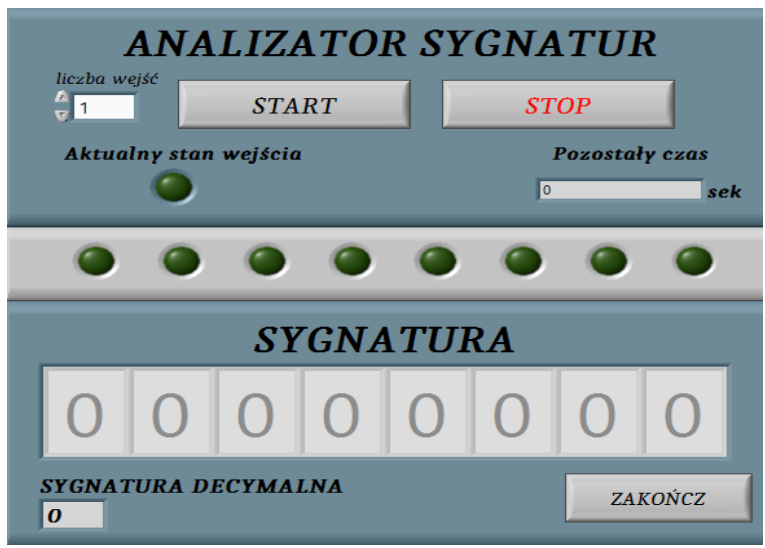

Rys. 4 Panel czołowy aplikacji Analizatora Sygnatur

Stanowisko laboratoryjne analizatora sygnatur składa się z: komputera PC z wykonaną aplikacją, modułu akwizycji danych NI 6008 i układu kombinacyjnego, realizującego pewną funkcję.

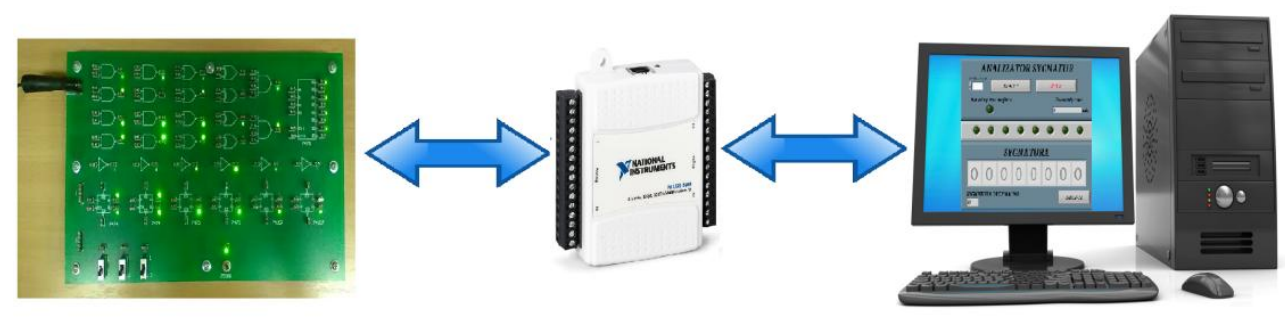

Rys. 5 Schemat stanowiska laboratoryjnego 
Laboratory station for reliability testing of digital circuits using signature analysis Stanowisko laboratoryjne do badania niezawodności układów cyfrowych...

Po uruchomieniu aplikacji użytkownik może zadeklarować liczbę wejść analizowanego układu, na które będzie podawana sekwencja testowa. Umożliwienie wprowadzenia liczby wejść układu badanego sprawia, że program jest uniwersalny i nadaje się zarówno do prostych układów logicznych jak i bardziej złożonych. Dodatkowo funkcja ta pozwala na przebadanie układu w różnych jego punktach. Po kliknięciu przycisku START, program rozpoczyna generację sygnatury. Proces ten można na bieżąco obserwować na ośmiu „diodach" umieszczonych w środkowej części panelu. Dodatkowo wyświetlana jest informacja o czasie pozostałym do końca analizy oraz aktualnym stanie wyjścia badanego układu. Po zakończeniu analizy na ekranie pojawia się sygnatura w postaci binarnej oraz decymalnej. Ze względu na przeznaczenie dydaktyczne programu czas generowania poszczególnych stanów testowych wynosi 1 sekunda. Umożliwia to bieżące obserwowanie zmian stanów w rejestrze przez studentów.

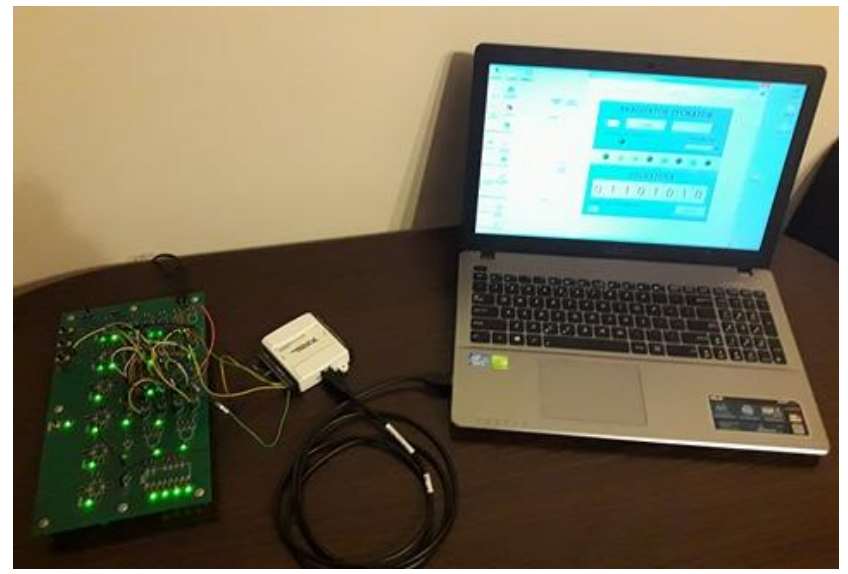

Rys. 6 Stanowisko laboratoryjne

\section{Badanie układu logicznego}

Zaprezentowany program analizatora sygnatur wykorzystano do przebadania układu logicznego, zbudowanego na bramkach, posiadającego 4 wejścia i 1 wyjście. Schemat układu oraz tablicę prawdy przedstawiono na rysunku 7. 


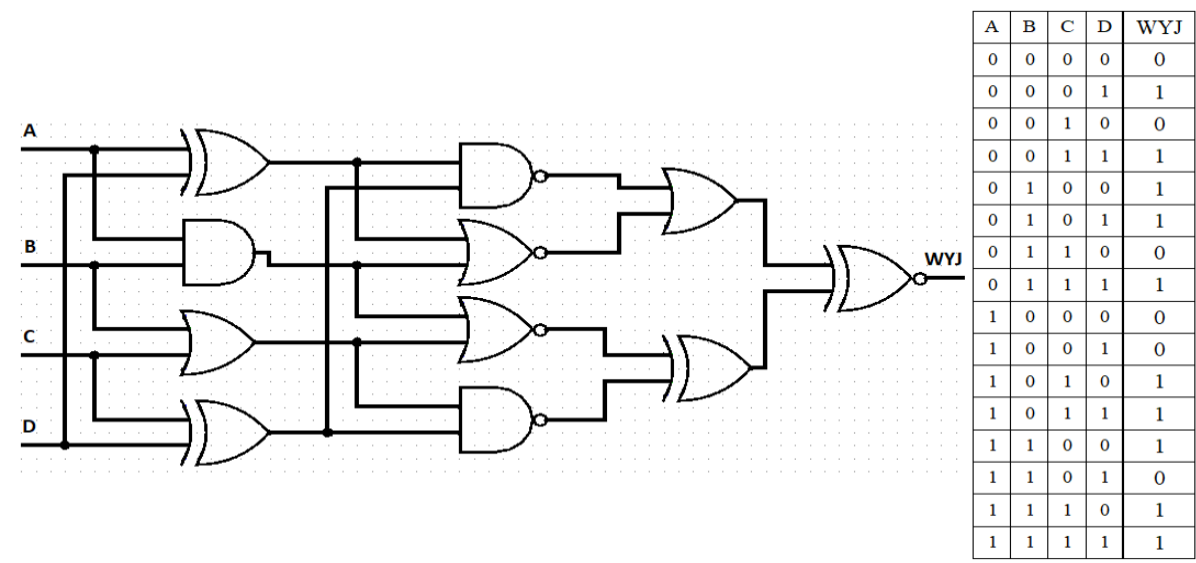

Rys. 7 Schemat badanego ukladu i tablica prawd

Badany układ został podłączony do modułu akwizycji danych NI 6008, który odpowiada za komunikację $\mathrm{z}$ komputerem. Na panelu czołowym aplikacji wprowadzono odpowiednią liczbę wejść, w przypadku tego układu 4. Po wciśnięciu przycisku START, rozpoczyna się proces wyznaczania sygnatury. Widok panelu w czasie generowania sygnatury przedstawiono na rysunku 8.

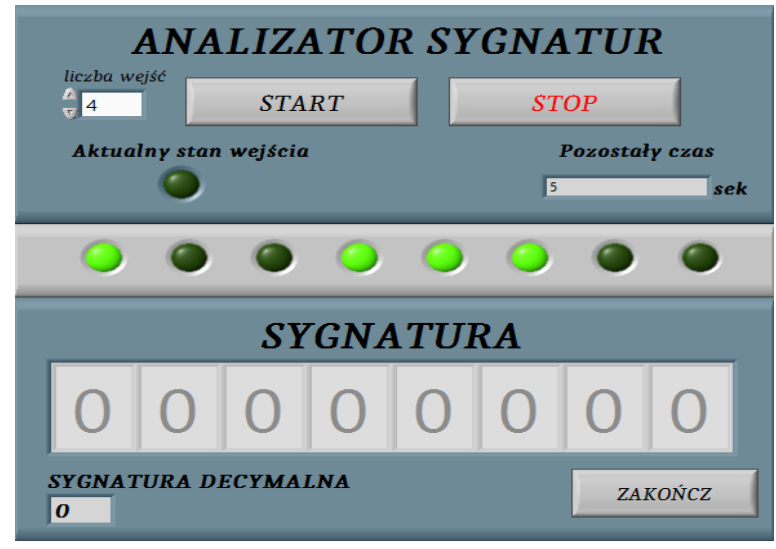

Rys. 8 Widok panelu czolowego podczas generowania sygnatury

Podczas pracy programu, na wejście układu badanego podawane są wszystkie możliwe stany, a z wyjścia zostaje odczytana odpowiedź na podstawie której generowana jest sygnatura. Po zakończeniu pracy programu $\mathrm{z}$ wyświetlacza można odczytać utworzoną 8-bitową sygnaturę.

Po przeprowadzeniu testu na poprawnie działającym układzie wprowadzono kolejno 2 uszkodzenia w losowo wybranych miejscach układu. Jako uszkodzenie przyjęto podanie ,zera” na wejście bramki, w miejscu zaznaczonym na rysunkach 10 i 11. 
Laboratory station for reliability testing of digital circuits using signature analysis Stanowisko laboratoryjne do badania niezawodności ukladów cyfrowych...

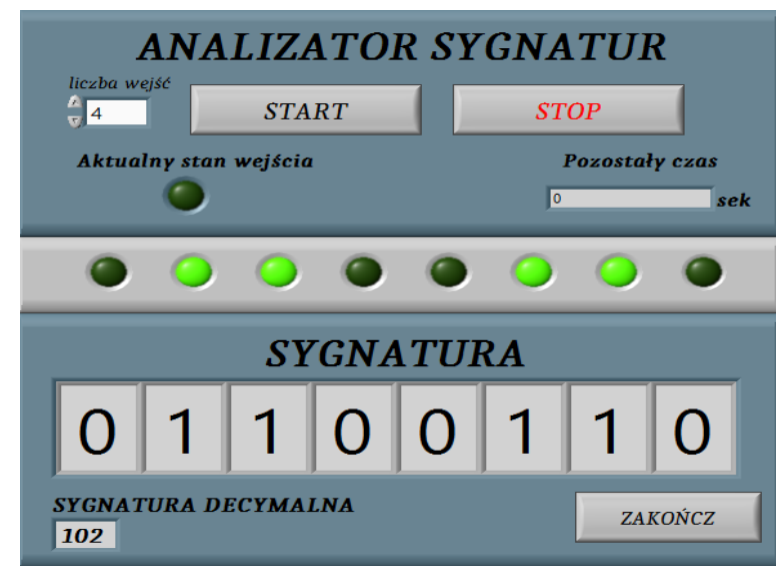

Rys. 9 Widok panelu czołowego po wykonaniu analizy

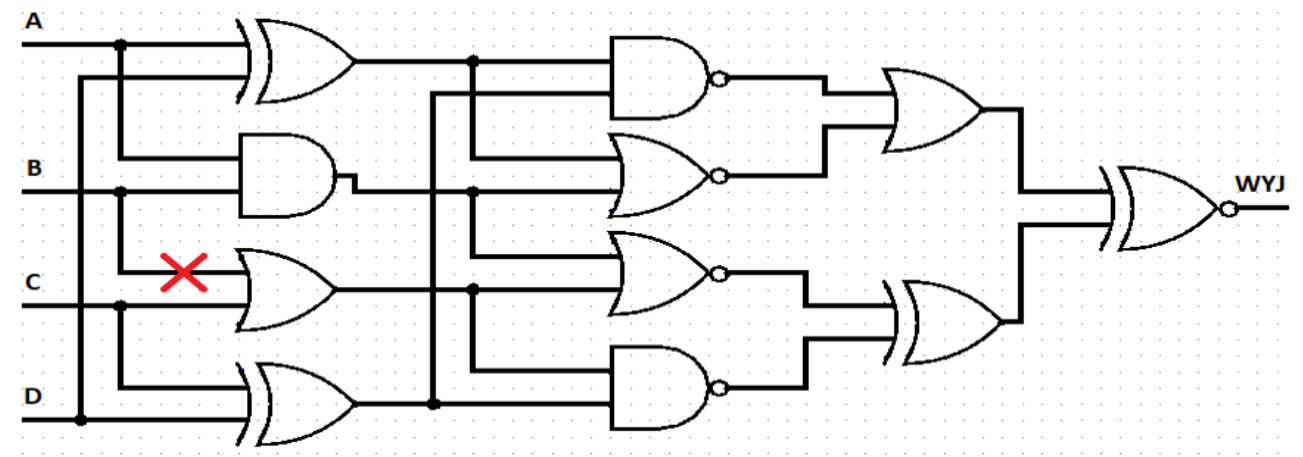

Rys. 10 Badany uktad z wprowadzonym uszkodzeniem 1

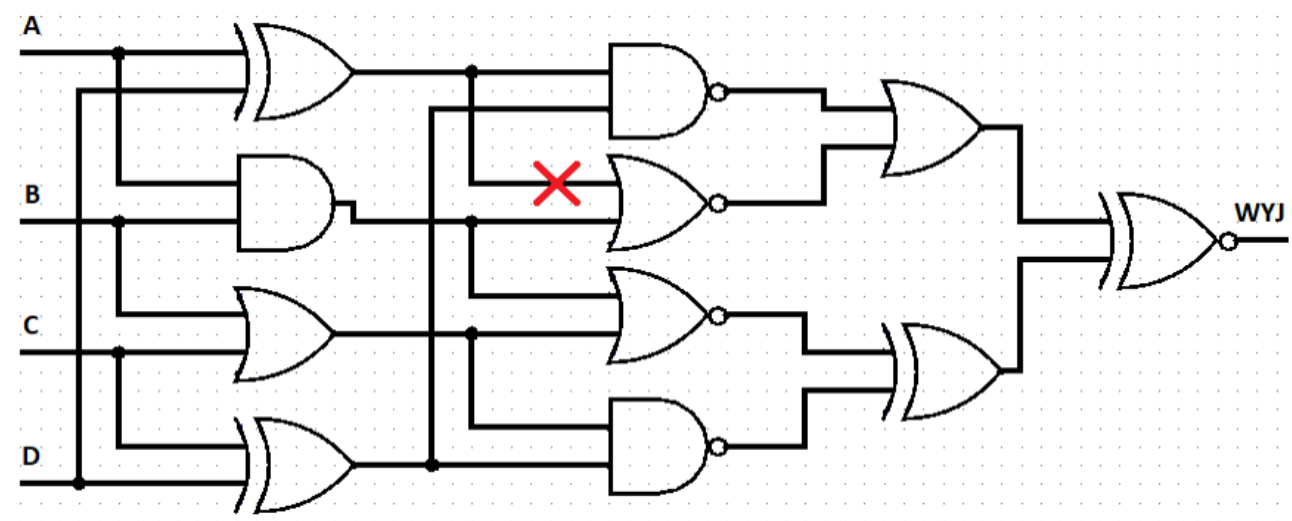

Rys. 11 Badany uklad z wprowadzonym uszkodzeniem 2

Ponownie przeprowadzono analizę, tym razem otrzymując sygnatury przedstawione na rysunku 12 i 13 . 


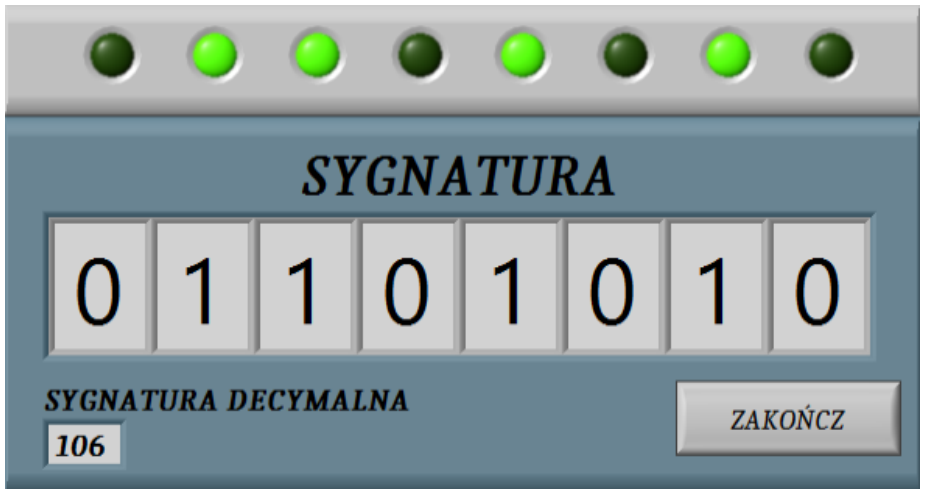

Rys. 12 Sygnatura otrzymana dla uszkodzonego układu - uszkodzenie 1

Można zauważyć że sygnatura otrzymana w wyniku poprawnego działania układu jest inna niż w przypadku układu z uszkodzeniami. Dodatkowo dla każdego $\mathrm{z}$ uszkodzeń otrzymano inną sygnaturę.

Tab.2 Sygnatury otrzymane w wyniku analizy

\begin{tabular}{|c|c|}
\hline Uszkodzenie & Sygnatura \\
\hline BRAK & 011100110 \\
\hline 1 & 00000001010 \\
\hline 2 & 0111001010 \\
\hline
\end{tabular}

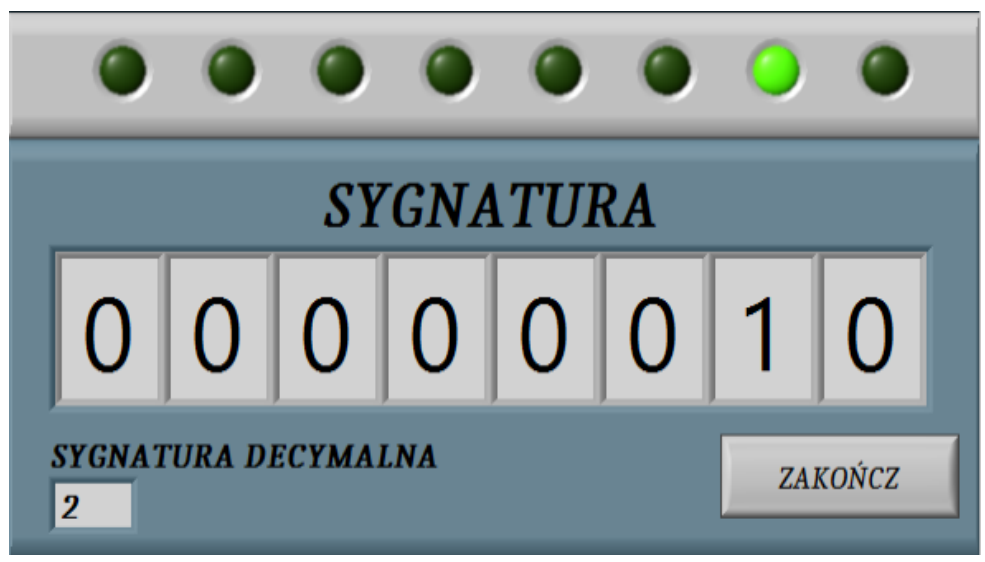

Rys. 13 Sygnatura otrzymana dla uszkodzonego układu - uszkodzenie 2

\section{Wnioski}

W artykule przedstawiona została technika diagnozowania układów cyfrowych zwana analizą sygnatur. Zaprezentowano program Analizatora Sygnatur wykonany w środowisku LabVIEW z użyciem modułu akwizycji danych NI 6008. Został on opracowany w celach dydaktycznych, aby zapoznać studentów z techniką cyfrową oraz jedną z metod testowania układów cyfrowych. 
Laboratory station for reliability testing of digital circuits using signature analysis Stanowisko laboratoryjne do badania niezawodności układów cyfrowych...

Przedstawiono działanie opracowanego programu, na przykładzie wybranego układu cyfrowego. Wyznaczono sygnaturę układu pracującego poprawnie, następnie wprowadzono kolejno dwa losowe uszkodzenia i porównano sygnatury. Przykładowe ćwiczenie laboratoryjne, może polegać na wyznaczeniu sygnatur każdego węzła zaprojektowanego wcześniej przez studentów układu kombinacyjnego. Następnie przez prowadzącego ćwiczenie do układu wprowadzone zostanie pojedyncze uszkodzenie. Zadaniem studentów będzie odnalezienie miejsca wystąpienia awarii poprzez wyznaczenie sygnatur poszczególnych węzłów $\mathrm{i}$ porównanie ich $\mathrm{z}$ tymi otrzymanymi wcześniej. Wykonany Analizator Sygnatur można wykorzystać do utworzenia biblioteki sygnatur, w której opisane będą uszkodzenia odpowiadające danym sekwencjom. Taka biblioteka w przyszłości znacznie uprości sprawdzanie poprawnego działania systemu cyfrowego i pozwoli na szybką diagnozę w przypadku wystąpienia awarii.

\section{Literatura}

[1] Frohwerk, Robert A. "Signature analysis: A new digital field service method." Hewlett-Packard Journal 28.9 (1977): 2-8.

[2] Chruściel, Marcin. LabVIEW w praktyce. Wydawnictwo btc, 2008.

[3] Głocki, Wojciech. Układy cyfrowe: podręcznik dla technikum. WSiP, 1996.

[4] Holdsworth, Brian, and Clive Woods. Digital logic design. Newnes, 2002.

[5] Parchański, Józef. Miernictwo elektryczne i elektroniczne. WSiP, 2014.

[6] Tłaczała, W. "Środowisko LabVIEW w eksperymencie wspomaganym komputerowo Wyd." Naukowo Techniczne Warszawa (2002).

[7] Wang, Francis. "BIST using pseudorandom test vectors and signature analysis." Custom Integrated Circuits Conference, 1988., Proceedings of the IEEE 1988. IEEE, 1988.

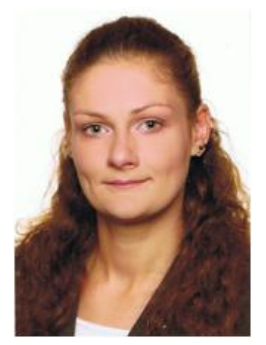

Mgr inj. Kamila Jadczak - asystent naukowo-dydaktyczny w Zaktadzie Systemów Informacyjno-Pomiarowych Wojskowej Akademii Technicznej. Zainteresowania naukowe obejmuja zagadnienia m.in. nauczania maszynowego oraz elektroniki w medycynie.(Udziat 50\%)

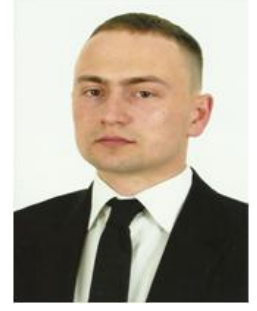

Mgr inz. Rafal Bialek-asystent naukowo-dydaktyczny w Zaktadzie Systemów Informacyjno-Pomiarowych Wojskowej Akademii Technicznej. Zainteresowania naukowe obejmuja pomiary wysokomocowych impulsów elektromagnetycznych oraz projektowanie ukladów impulsowych dużej mocy. (Udziat 50\%) 